\title{
Supporting children with communication aids in transition: the perspective of children and adults involved with the Communication Aids Project (CAP)
}

Caroline Newton ${ }^{1}$, Jannet A. Wright ${ }^{2}$, Michael Clarke ${ }^{1}$, Chris Donlan ${ }^{1}$, Claire Lister $^{3}$ and Jasmina Cherguit ${ }^{4}$

${ }^{1}$ Department of Human Communication Science, University College London, Chandler House 2 Wakefield Street, London WC1N 1PF

${ }^{2}$ School of Allied Health Sciences, Faculty of Health and Life Sciences, De Montfort University, The Gateway, Leicester LE1 9BH

${ }^{3}$ Conference Services, The Institute of Child Health, 30 Guilford Street, London WCIN 1EH

${ }^{4}$ Redford Lodge Psychiatric Hospital, 15 Church Street, Edmonton, London N9 9DY

Address for correspondence:

Dr. Caroline Newton

Department of Human Communication Science

University College London

Chandler House

2 Wakefield Street

London WC1N 1PF

Email caroline.newton@ucl.ac.uk

Tel: 020-7679-4222 


\section{Introduction}

Transition from one educational setting to another at any stage in a child's education presents a range of challenges and opportunities for children themselves and for those who support and teach them. The challenges involved in transition may be exaggerated for children who use communication aids. Communication aids may be used to support children who have difficulties in communicating verbally, understanding language and/or using written communication. The aids range from voice output communication aids (VOCAs) which replace or augment a child's own speech to laptop computers with, for example, text-to-speech or word prediction software aimed at assisting users to access written language.

Those who use communication aids include a wide spectrum of children such as those who have difficulties with written language and who may find that their abilities are underestimated (for example, children with dyslexia, see Snowling \& Stackhouse, 1996). Also included in this group are children with physical disabilities, who have little or no functional speech and who may have significant difficulties in initiating and sustaining interaction (e.g. Clarke \& Kirton, 2003). Both groups are at risk of not achieving their full potential at school and face additional challenges in the transition between educational settings: 'When communication skills are impaired, the usual vulnerabilities of children at crucial stages in their school careers must be considerably heightened' (Donlan, 1998: 212).

Funded by the Department for Education and Skills (DfES), the Communication Aids Project (CAP) was introduced in 2002 to work in partnership with schools and LEAs to supply equipment to both groups of students mentioned above as well as others with difficulties such as hearing or visual impairment. Equipment was supplied in order to 'help them access the curriculum and interact with others and support their transition to post-school provision' (http://cap.becta.org.uk). CAP also aims to help schools and LEAs to develop skills and awareness in the area of communication difficulties. 
The research reported here forms part of an independent evaluation of CAP (Wright et al., 2004), in which children with communication aids, their parents, teachers and speech and language therapists were interviewed about their experience of CAP and the use of the communication aid. The research reported here focuses particularly on the impact of the communication aid on transition, and the impact of transition on use of the communication aid.

Children can be involved in the transition process at many stages in their educational career, for example transferring from primary school to secondary school. Children face changes when they enter school, move from infant to junior school, from a special school to mainstream school or vice versa and also when they move from school to post-16 provision (e.g. college) and become the responsibility of the adult health and education services. All these moves require preparation, discussion of concerns, planning and support.

It is widely reported that a transfer from one school to another can have an adverse effect on a child's motivation and performance (see, for example, Roderick, 1993; Galton et al., 1999). Galton, Morrison \& Pell (2000) suggest that as many as $40 \%$ of pupils transferring from primary to secondary school 'experience a hiatus' in academic progress. This may be a result of different teaching methods and demands made on pupils in the new setting and/or the failure of children to adapt to these changes.

Galton et al. (2000) also note the effects of transition on pupils' levels of anxiety, enjoyment of school and motivation for school work and that these are more marked in children transferring from primary to secondary school. In their review of literature in this area, Anderson et al. (2000) summarise the particular challenges confronting pupils at transition to secondary school, including increased size of school campus and pupil numbers; decreased personal relations with teachers; a change in focus from effort and improvement to ability and competition; making and maintaining new relationships with other pupils. They comment that ensuring that a pupil is well prepared for the transition (both academically and in terms of awareness of the relevant issues) and well supported by parents, peers and teachers will be valuable in increasing the chance of a successful 
transition. Students who do not feel welcomed or valued at transition are in danger of feeling anonymous and eventually disengaging from school.

Currently, support for pupils at transition is focussed on preparation, in the form of Transition Programmes, which might involve, for example, induction days for new pupils at a primary setting or a tour of a new secondary school for older children. Several researchers (Sanders et al., 2005; Graham \& Hill, 2003) report positive effects and perceptions of these programmes by parents, staff and children. There is a growing awareness, however, that students need continued support in adjusting to life after a transfer to a new school (see, for example, Graham \& Hill, 2003; Galton et al., 2003), not least because each subsequent year in education will also involve a transition with its own challenges to motivation and performance: 'attention needs to be directed more evenly across the whole of the middle years or each phase of schooling as students move from one year to another' (Demetriou et al., 2000:439).

Effective communication between members of staff and between staff and parents is a key element in successful transition. In their study of the effectiveness of transition from Foundation Stage (involving children ages three to five years) to Key Stage 1 (for children aged five to six years), Sanders et al. (2005) report parents' appreciation of efforts made by schools to provide information on their child's new setting and to offer meetings with relevant staff and opportunities to accompany their child on a visit to the school.

Good communication between school and staff and parents is particularly needed for pupils with special educational needs (SEN), who face particular challenges at transition. The SEN Code of Practice (DfES, 2001) notes that it is important that information about pupils' personal and academic details should move smoothly from one school to the next when they transfer at Key Stage 2 (age 11), both in terms of transfer of school records and close liaison between schools.

Much of the literature on children with SEN in transition has focussed on the transition from compulsory schooling to further education and adult life. One major theme here is parents' and 
carers' desire for more information on, for example, the transition process in general, the range of options available to their children and which agencies are responsible for which aspects of the process. As one researcher in the field comments: "parents simply want more information and they want it earlier on in the transition process... [They] will actively co-ordinate, pester and push agencies providing they know what they should have, who should be providing it and when it should happen' (Smart, 2004:135).

While parents and carers are willing to act on behalf of their children in the transition process and often take the key role in working towards a successful transition, many report serious frustrations with the process. These include the battle to get the required support for the young people. Often support is only offered when it is requested or when obvious difficulties arise (Aston et al., 2005).There can be difficulties in identifying who - in terms of an individual, organisation or agency - has overall responsibility for this process. Band et al. (2002) carried out a set of interviews with parents of children with speech and language needs, and report that respondents showed 'no perception' of a plan involving collaboration between health and education professionals which would oversee the transition process. Botting et al. (1998) also highlight the clear need for appropriate support for children with language difficulties in transition, particularly to Key Stage 2. Some parents have suggested a named co-ordinator for each child would be useful (Ward et al., 2003).

Those involved also report differing experiences of preparation for transition according to educational setting. Polat et al. (2001) report $64 \%$ of parents and carers with children at special schools satisfied with schools' preparation for transition contrasting with $44 \%$ of parents of pupils in mainstream schools.

Similar themes to these were picked up in research carried out as part of the RITE Project ( http://www.ritesite.org.uk)., which focuses on young people with complex physical and/or communication needs but without significant learning difficulties who are moving from school to Further Education and independent adulthood. The majority of the young people involved in that 
project will use communication aids. Young people and their parents expressed a need for ongoing assessment and clearer information on choices and funding opportunities as well as information regarding lines of responsibility. One recommendation from the project is that each student in transition should be assigned a key worker who will oversee the process and provide support and advice to young people and parents

The research reported here provides a useful insight into communication aid users' earlier experiences of transition both between schools and within the same school: how having a communication aid has impacted on their experience of transition and how transition has influenced their use of the aid.

\section{Participants}

Participants were twelve children who were at transition points in education, their parents, teachers and, where appropriate, their speech and language therapists. Table 1 shows the profile of the children included in the study, with ages ranging from 8.00 years to 17.01 years. Eight children had recently transferred from primary to secondary setting, one from infant to primary and three from secondary to post-16 provision. Seven of the children attended special schools and five were in mainstream education. There were six VOCA users and six children who had been provided with a laptop. The sample includes children who had been diagnosed with a range of different difficulties and syndromes, including cerebral palsy and dyslexia. In addition to the children, we interviewed twelve parents, twelve teachers and five speech and language therapists.

\section{INSERT TABLE 1 ABOUT HERE}

On analysing the data it was important to be aware of the potential problems arising from the relative heterogeneity of the sample in terms of age, educational setting, diagnosis and type of aid used (as shown in Table 1). While the perspectives of the individuals involved related to their own diverse experiences, clear common themes emerged as the data was closely examined. These are the focus of this paper. 


\section{Interviews}

Interviews with the children took place on a one-to-one basis and where appropriate used their communication aid. The interviews aimed to explore the value of CAP-funded communication aids within the experience of transition. First, young people were asked to identify a number of communication-focused activities that they recognised as relevant to their experience of transition, such as talking to new people and new teachers, planning work and spelling. These chosen activities were divided into those in which the communication aid was used/available/relevant and those in which it was not. The activities in which the communication aid was used/available/ relevant were then located on two scales: one representing the degree of importance attached to the activity, and secondly, a dimension representing how valuable (useful) the communication aid had been. See the full report of the project (Wright et al., 2004) for further details on the interview procedure.

The interview procedure was designed to allow children with a range of communication difficulties to respond and express their views even if they were non-speaking.

Telephone interviews were conducted with parents and professionals. The main themes of the interviews with parents focused on background to the assessment; how their child had benefited or otherwise from aid provision within transition; the impact of the aid on the process of transition; differences between old and new settings in terms of support available and use of the aid and how they might improve the process. Interviews with professionals concerned their experiences of the CAP process; use of the aid and the impact of the communication aid in the process of transition (see Table 2 for further details on the content of the telephone interviews)

\section{INSERT TABLE 2 ABOUT HERE}

All the adults interviewed were sent a copy of the interview schedule before the interview. Telephone interviews were recorded using ${ }^{C T I} P$ ulsar $P C$ telephone and room recorder. 
All the telephone interviews were transcribed and were analysed using a Grounded Theory approach (Strauss \& Corbin, 1998). In this approach interviews were constantly re-read and compared and common themes were identified in the data. Children were asked to give information on the impact of the aid in their new educational setting; parents and professionals interviewed raised additional issues such as the portability and security of communication aids, managing the flow of information between schools and the need for training of educational staff in a new setting.

\section{Findings of the study}

Participants in the study reported positive effects of the communication aid on the lives of the individual children, including school and communication activities relevant at transition. Issues of concern raised - in order to gain the most from aids at and after transition - included the ability to carry an aid around a new school and store it securely when necessary, the flow of information between schools on the children and the aids, and the need for training for staff in the new setting unfamiliar with the aids and their uses.

\section{The impact of the aid on transition}

The parents of children in transition were very positive about the impact that the communication aids provided by CAP were having on their children's lives, their communication and school work. For some children transition within the same school or to a different school had been a positive experience for all involved, particularly for the seven children whose move was to a special school Teachers and SLTs at special schools commented on the benefits of moving to a school with specialist staff and high levels of both support for the children themselves and IT support for the aids. There were concerns, though, that if the child were to move with an aid to a school without such support the transition might not be so smooth. 
For one child involved in the study, the transition from primary to senior setting within the same school offered a new opportunity to make full use of the aid in class. While in the child's previous class the voice output communication aid he was provided with had been used infrequently, at transition the new teaching staff were trained and were equipped to encourage use of the aid and to incorporate it into lessons.

One teacher commented that she thought that a child joining her class that year had benefited in that transition from having 'his trusty VOCA'. She felt that this was because:

'it was something that was the same, I mean he was in a different classroom with different teachers, but his communication aid came with him so it was familiar thing in a new setting. So I think that it probably did help him settle.'

The young people interviewed expressed positive views concerning the value of their CAP funded communication aids in a range of activities. With any change of school there is a need to make new friends and it was apparent that some of the children felt that a communication aid helped them to make friends, and assisted them in a range of other activities relevant at transition, such as talking to a new teacher and visiting new places.

Figures 1 and 2 show the range and frequency of quality of life indicators chosen by the young people to represent their own experience of how their aid helped them during transition. For those using aids to support recording and/or understanding the most frequently chosen factors were:

- feeling satisfied

- feeling in control

- feeling like the work being produced is their own

The most frequently chosen factors by children with VOCAs were:

- getting a turn to speak

- being treated fairly

- $\quad$ being able to say what they are thinking or feeling 
- being able to make choices

INSERT FIGURE 1 ABOUT HERE 


\section{INSERT FIGURE 2 ABOUT HERE}

Muhammad is a young person with Dystonic Cerebral Palsy, which means he has profound difficulties controlling physical movements and in generating speech. CAP provided Muhammad with a Pathfinder communication aid and individually designed head switches that aimed to maximise access while reducing the possibility of a damaging decline in his posture. When interviewed, Muhammad had recently moved from the secondary department of his special school to a post 16 education department.

At interview Muhammad identified six communication-focused activities that were relevant to his experience of transition (see Table 3). Without exception, he reported that his communication aid had been useful in each activity. Interestingly, he reported that the most important of these activities were using the communication aid in meetings; in talking to new people and in making new friends.

\section{INSERT TABLE 3 ABOUT HERE}

The children at transition also valued the way in which an aid enabled them to show their abilities in the new setting. For example, Robert who is 11 years of age experiences significant difficulties with his memory. CAP provided Robert with a personal laptop computer and a suite of software to support him across a range of classroom activities. When interviewed Robert recognised six activities that reflected his own everyday experience in his new school, and reported that he found his communication aid was most useful in supporting planning work, spelling and handwriting (presentation of work). Of these three activities he identified spelling and handwriting as being most important at his new school (see Table 4).

\section{INSERT TABLE 4 ABOUT HERE}


For several children, however, a move within the same school and especially between schools raises several new issues about the use of the aid. A transition from a junior to senior setting will involve a change from having a single class teacher and support assistant in one classroom to a number of different teachers in a number of different classrooms in the school. The challenges for parents, professionals and children when there is a move to a senior school seem to be about managing the information provided to the variety of education staff involved on the use of the aid and the portability and security of aids, especially laptops, when they need to be taken between classrooms.

\section{Portability and security}

Students with laptops faced particular challenges because laptops were often reported to be large and heavy for children to carry around. This was commented on more frequently for children who had just moved to secondary school. This appears to be more of a problem at secondary school because children move around from classroom to classroom much more than they had done at primary school and the laptop has to be taken with them to each lesson.

While in junior school, security was not such a major issue as the laptop could be chained and locked in the classroom, this was not possible when children were moving from one room to another during the day. As two parents commented:

'It's just too heavy, with his books and PE kit'

'he's got a locker, but it's too big for the locker, so it has to be kept in the learning support unit'.

This inevitably affected the use of the aid, as the child often had to collect it from a separate part of the school for particular classes. This usually meant that the aid was being used less often than hoped. While children were often encouraged to collect the aid this would mean that the start of lessons was delayed while the child collected the aid. 
Parents, teachers and speech and language therapists especially identified two areas that could be addressed to make transitions easier for all involved to increase knowledge in the new school on the aid itself and on the use of the aid in different classroom activities - managing information and training.

\section{Managing information}

Several parents and teachers suggested that one of the main factors in ensuring the appropriate use of the communication aid in a new school is helpful flow of information between schools and between staff in the same school. In most cases it was the SENCo who was to take responsibility for ensuring all the relevant staff in their setting were fully informed about the aid. One SENCo commented that she felt 'I'm the key person who pushes the use of [the aid].'

Teachers acknowledged that the flow of information between schools could often be improved, even though there were usually close links between special educational needs departments in both schools. SENCos interviewed commented that some contact from CAP when the aid arrived would have been helpful. One SENCo, though experienced with supporting literacy at school would have appreciated more support on how to make best use of the laptop provided for a hearing impaired child at the school.

Another SENCo suggested that a named contact (perhaps provided by CAP) to whom both the primary school staff and she would be able to turn for advice on using the aid and training would have been beneficial. She had considered arranging for the learning support assistants (LSAs) most closely involved with the child to be trained, but was reluctant to do this as she did not want to add to the burdens of already 'underpaid' and 'over-stretched' LSAs. She thought that training might not be CAP's responsibility but it would have been really useful to have had someone to discuss the issue with. 
It would have been useful actually to have a contact person or phone number, perhaps kind of highlighted that the SENCo at the primary school would have also have known... you know that yes this is the person that you could contact and they'll come in and liaise with you, they'll train'.

The adults interviewed also recognised the need for good exchange of information on a child's communication aid use not just at transition points between schools but also throughout their school life.

For example, Andrew has a laptop to support his work with written language. Both his parent and teacher recognise that the best use of it is not currently being made in his new school, and that raising awareness of the aid and increasing teachers' ability to incorporate the aid is relevant not just at transition but throughout his school life. 'I know he's going to struggle with reading or writing all the way through and my concerns are that unless all his teachers are aware, not just in the first year but every year, it's going to be harder and harder for him to cope with school life.'

\section{Training}

In addition to a contact person with whom both schools could liaise, parents and teachers particularly highlighted the need for better training for those working with children who have just moved schools. When staff in the new setting have been trained, the results are positive: 'I am encouraged by the fact that his current teacher... has now undergone a day's training on it, so they are really trying to get to grips with it.'

Teachers felt there was an expectation that information gained from the initial training on the aid would be passed on by the staff at the first school to the one to which the child was transferring. This did not always happen, and several teachers indicated that they would have appreciated specific training. Several of those interviewed said that it would have been helpful to train staff from both settings together. They thought that this had not been possible due to difficulties in releasing staff or liaising with a trainer. 
One child involved in the study has just moved from a special school to a mainstream setting. In this case the professionals involved were able to organise training which staff at both settings were able to attend. The SLT involved said: 'When we did the training we invited them because we knew he was going to be going... [it worked well] because it wasn't us going in telling them; we were all learning together, which made it more on equal footing'.

\section{Discussion}

When a child transfers from one school to another there is an awareness that support is required to ensure a smooth transition. Researchers have highlighted the usefulness of plans and programmes which prepare pupils for transition and the need for good communication and information flow between the schools involved. This is particularly true for children with special educational needs, including those who use communication aids.

Comments from participants in the study reported here suggest that more work is needed to ensure the better flow of information between schools especially on the use of the aid, whether the aid is a VOCA or a laptop. Several of those interviewed mentioned that a single contact person would be helpful, with whom parents and both schools could liaise. This echoes similar suggestions made by parents of children with special educational needs of the need for a named co-ordinator at transition (Ward et al., 2003). In the case of children with communication aids this individual could not only facilitate good information flow between schools but also be the source of information about the use of the aid in the classroom and on further training for relevant professionals.

Research in the area of transition in general has also raised the need for continued support as children progress from year to year at school. This is also crucial for children who use communication aids as they progress through the school years and also as they move between classes, with the differing demands and opportunities that different subjects provide. 
Many of the issues faced by children with communication aids in transition and those who support them are similar to all those involved in any pupil's transfer from one school to another, with the additional challenge of the aid itself. Educational staff will need to know how to use the aid and to use the software which comes with the aid, and they will need to know how to support the pupil's use of the aid, including ensuring optimum access to the aid (especially relevant when the child's aid is a heavy laptop which may need to be collected from a separate room when required). Similar issues were also identified by Priest \& May (2001), who found that the most important factors in the successful use of laptops in school by children with disabilities were portability and the ability of the teachers in adapting learning tasks appropriately.

It is evident that many mainstream schools may feel under-prepared for a communication aid arriving with a child, and that as the child settles into the school it is the SENCo who will carry the central role in promoting and ensuring the use of the aid. This will be a particularly challenging role for the SENCo in a secondary school where the special needs department would potentially be responsible for a large number of children with diverse needs and where a large number of teachers are likely to be involved in teaching a child with a communication aid. Both here and in primary schools it is essential that other staff are involved in ensuring a communication aid is being utilised to its greatest potential.

This could be accomplished by raising general awareness of all school staff about communication aids, the possible communication difficulties of the children they support and the kinds of support with spoken or written language aids offer. It would also be useful to involve a greater number of staff in taking on the aid and ensuring it was being used appropriately. Such staff could include others who work in the SEN department and Learning Support Assistants.

Support for the SENCo and other staff may be available outside individual schools from Local Education Authorities (LEAs) and from those who have been involved in the Communication Aids Project (CAP). CAP is due to end in March 2006, but much of the expertise which the project has built on and developed will still be available. For example, CAP used existing skills and knowledge 
at six specialist centres across the UK (Abilitynet, ACE North, ACE Oxford, Deaf Children's Communication Aids Project (DCCAP), London CAP and SCOPE) and set up a network of 'CAP contacts' who were involved in assessment for communication aids and support for aid users. Both of these would be possible sources of information for professionals. In addition, many LEAs may have specialists in this area.

All children with special educational needs face particular challenges at points of transition; for the group of children reported here there is an additional - possibly unrecognised - need for training in technology for those who work with them. If this is not arranged well then the child may find their use of their communication aid will not develop. Participants in this study expressed positive views on the value of a communication aid in transition. Some children interviewed stated that their communication aid helped them to get to know a new teacher and new friends, while others found their aid useful in demonstrating their abilities (e.g. planning and writing pieces of work) in a new environment. It is vitally important, therefore, that at transition teachers and parents of children who use communication aids enable and encourage appropriate use of aids to ensure that each child can achieve his or her full potential at school.

\section{Acknowledgements}

We would like to thank all the children, parents, education staff and Speech and Language Therapists who gave their time to participate in this study. The evaluation study was funded by the Department for Education and Skills (DfES). All views expressed in here are those of the authors and do not necessarily reflect those of the DfES.

\section{References}

ANDERSON, L.W., JACOBS, J., SCHRAMM, S. \& SPLITTGERBER, F. (2000). School transitions: beginning of the end or a new beginning? International Journal of Educational Research, 33, 325339 
ASTON, J., DEWSON, S., LOUKAS, G. \& DYSON, A. (2005). Post-16 transitions: a longitudinal study of young people with special educational needs (Wave three). (DfES Research Report RB655). London: DfES

BAND, S., LINDSAY, G., LAW, J., SOLOFF, N., PEACEY, N., GASCOIGNE, M. \& RADFORD, J. (2002). Are Health and Education talking to each other? Perceptions of parents of children with speech and language needs. European Journal of Special Needs Education, 17, 211-227

BOtTING, N., CRUTCHLEY, A. \& CONTI-RAMSDEN, G. (1998). Educational transitions of 7year-old children with SLI in language units: a longitudinal study. International Journal of Language \& Communication Disorders, 33, 177-197

CLARKE, M.T. and KIRTON, A. (2003) Patterns of interaction between children with physical disabilities using augmentative and alternative communication and their peers, Child Language Teaching and Therapy, 19, 135-151

DEMETRIOU, H., GOALEN, P. \& RUDDUCK, J. (2000). Academic performance, transfer, Transition and friendship: listening to the student voice. International Journal of Educational Research, 33, 425-441

DEPARTMENT FOR EDUCATION AND SKILLS (2001) Special Educational Needs Code of Practice. London: DfES

DONLAN, C. (1998). The importance of educational transitions. International Journal of Language \& Communication Disorders, 33, 212-215

GALTON, M., GRAY, J. and RUDDUCK, J. with BERRY, M., DEMETRIOU, J., EDWARDS, J., GOALEN, G., HARGREAVES, J., HUSSEY, S., PELL, T., SCHAGEN, I. and CHARLES, M. 
(2003). Transfer and Transitions in the Middle Years of Schooling (7-14): Continuities and Discontinuities in Learning (DfES Research Report 443). London: DfES

GALTON, M., MORRISON, I. \& PELL, T. (2000). Transfer and transition in English schools: reviewing the evidence. International Journal of Educational Research, 33, 341-363

GALTON, M., GRAY, J. \& RUDDUCK, J. (1999). The impact of school transitions and transfers on pupil progress and attainment. (DfEE Research Report RR131). London: DfES

GRAHAM, C. and HILL, M. (2003). Negotiating the Transition to Secondary School (SCRE Spotlight 89). Glasgow: University of Glasgow, SCRE Centre.

POLAT, F., KALAMBOUKA, A., BOYLE, W.F. \& NELSON, N. (2001). Post-16 transition of pupils with special educational needs. (DfES Research Report RR315). London: DfES

PRIEST, N. \& MAY, E. (2001). Laptop computers and children with disabilities: factors influencing success. Australian Occupational Therapy Journal, 48, 11-23

RODERICK, M. (1993). The path of dropping out. Westport, CT: Auburn House

SANDERS, D., WHITE, G., BURGE, B., SHARP, C., EAMES, A., McEUNE, R. and GRAYSON, H. (2005). A Study of the Transition from the Foundation Stage to Key Stage 1. (DfES Research Report SSU/2005/FR/013). London: DfES.

SMART, M. (2004). Transition planning and the needs of young people and their carers: the alumni project. British Journal of Special Education, 31, 128-137

SNOWLING, M. and STACKHOUSE, J. (1996) Dyslexia, Speech and Language : A Practitioner's Handbook. London: Whurr Publishers 
STRAUSS, A.L., \& CORBIN, J. (1998) Basics of qualitative research: techniques and procedures for developing grounded theory. London: Sage

WARD, L., MALLETT, R., HESLOP, P. \& SIMONS, K. (2003). Transition planning: how well does it work for young people with learning disabilities and their families? British Journal of Special Education, 30, 132-137

WRIGHT, J., CLARKE, M., DONLAN, C., LISTER, C., WEATHERLY, H., NEWTON, C., CHERGUIT, J., \& NEWTON, E. (2004). Evaluation of the Communication Aids Project (CAP). (DfES Research Report RR580). London: DfES. 
Table 1 Profile of children interviewed at transition

\begin{tabular}{|c|c|c|c|c|c|c|c|c|}
\hline Child & Age & Sex & Diagnosis & Aid & $\begin{array}{l}\text { Access } \\
\text { Method }\end{array}$ & Mobility & $\begin{array}{l}\text { Old } \\
\text { Location }\end{array}$ & New location \\
\hline 1 & 8.00 & $M$ & PBSNHL & Laptop & D & Amb't & $\begin{array}{l}\text { Infant } \\
\text { Mainstream }\end{array}$ & $\begin{array}{l}\text { Primary } \\
\text { Mainstream }\end{array}$ \\
\hline 2 & 11.08 & $M$ & $\begin{array}{l}\text { Cerebral } \\
\text { Palsy }\end{array}$ & VOCA & D & WCh & $\begin{array}{l}\text { Primary } \\
\text { Special }\end{array}$ & $\begin{array}{l}\text { Secondary } \\
\text { Special } \\
\text { (part-time) }\end{array}$ \\
\hline 3 & 11.08 & M & GDD & VOCA & D & Amb't & $\begin{array}{l}\text { Primary } \\
\text { Special }\end{array}$ & $\begin{array}{l}\text { Secondary } \\
\text { Special }\end{array}$ \\
\hline 4 & 11.09 & M & $\begin{array}{l}\text { Cerebral } \\
\text { Palsy }\end{array}$ & VOCA & D & WCh & $\begin{array}{l}\text { Primary } \\
\text { Special }\end{array}$ & $\begin{array}{l}\text { Secondary } \\
\text { Special }\end{array}$ \\
\hline 5 & 11.11 & M & Unknown & Laptop & D & Amb't & $\begin{array}{l}\text { Primary } \\
\text { Mainstream }\end{array}$ & $\begin{array}{l}\text { Secondary } \\
\text { Mainstream }\end{array}$ \\
\hline 6 & 11.07 & M & $\begin{array}{l}\text { Dyslexia \& } \\
\text { oculomotor } \\
\text { difficulties }\end{array}$ & Laptop & D & Amb't & $\begin{array}{l}\text { Primary } \\
\text { Mainstream }\end{array}$ & $\begin{array}{l}\text { Secondary } \\
\text { Mainstream }\end{array}$ \\
\hline 7 & 11.08 & M & Dyslexia & Laptop & D & Amb't & $\begin{array}{l}\text { Primary } \\
\text { Mainstream }\end{array}$ & $\begin{array}{l}\text { Secondary } \\
\text { Mainstream }\end{array}$ \\
\hline 8 & 11.09 & M & $\begin{array}{l}\text { Memory } \\
\text { difficulties }\end{array}$ & Laptop & D & Amb't & $\begin{array}{l}\text { Primary } \\
\text { Mainstream }\end{array}$ & $\begin{array}{l}\text { Secondary } \\
\text { Mainstream }\end{array}$ \\
\hline 9 & 12.01 & $\mathrm{~F}$ & $\begin{array}{l}\text { Cerebral } \\
\text { Palsy }\end{array}$ & VOCA & $D$ & wCh & $\begin{array}{l}\text { Primary } \\
\text { Special }\end{array}$ & $\begin{array}{l}\text { Secondary } \\
\text { Special }\end{array}$ \\
\hline 10 & 16.11 & $\mathrm{~F}$ & $\begin{array}{l}\text { Joubert's } \\
\text { Syndrome }\end{array}$ & Laptop & D & Amb't & $\begin{array}{l}\text { Special } \\
\text { School }\end{array}$ & $\begin{array}{l}\text { Special } \\
\text { College }\end{array}$ \\
\hline 11 & 17.00 & M & $\begin{array}{l}\text { Cerebral } \\
\text { Palsy }\end{array}$ & VOCA & $\ln D$ & wCh & $\begin{array}{l}\text { Secondary } \\
\text { Special }\end{array}$ & $\begin{array}{l}\text { 6th form } \\
\text { Special }\end{array}$ \\
\hline 12 & 17.01 & M & None given & VOCA & $D$ & Amb't & $\begin{array}{l}\text { Secondary } \\
\text { Special }\end{array}$ & $\begin{array}{l}\text { Special } \\
\text { College }\end{array}$ \\
\hline
\end{tabular}


PBSNHL Profound bilateral sensori-neural hearing loss

D Direct (finger, eye or light beam pointing)

Amb't Ambulant

VOCA

Voice Output Communication Aid

WCh

\section{Wheelchair}

GDD

Global developmental delay

$\ln D$

Indirect (switch or partner scanning) 
Table 2. Details of interviews with parents, education staff and Speech and Language Therapists $(\mathrm{SLT})$

\begin{tabular}{|c|c|c|c|}
\hline $\begin{array}{l}\text { Background } \\
\text { information }\end{array}$ & Use of the aid & Transition issues & $\begin{array}{l}\text { Communication Aids } \\
\text { Project }\end{array}$ \\
\hline $\begin{array}{l}\text { Details on current } \\
\text { aid and any } \\
\text { previous aids }\end{array}$ & $\begin{array}{l}\text { Current use of the } \\
\text { aid (location and } \\
\text { activities) } \\
\text { Perceived } \\
\text { benefits of aid so } \\
\text { far and expected } \\
\text { long-term benefits } \\
\text { Views on } \\
\text { children's } \\
\text { interpersonal } \\
\text { relationships and } \\
\text { experiences with } \\
\text { the aid } \\
\text { Education staff: + } \\
\text { views on the } \\
\text { child's current } \\
\text { involvement in the } \\
\text { classroom, written } \\
\text { work and } \\
\text { relationships at } \\
\text { school } \\
\text { SLT work }\end{array}$ & $\begin{array}{l}\text { - The impact of the } \\
\text { aid on } \\
\text { transfer/transition } \\
\text { - Any difference } \\
\text { between old and } \\
\text { new setting in use of } \\
\text { the aid and support } \\
\text { for its use } \\
\text { The co-ordination of } \\
\text { services during } \\
\text { transition }\end{array}$ & $\begin{array}{l}\text { - Satisfaction with the } \\
\text { CAP process } \\
\text { improvements } \\
\text { - Any concerns for } \\
\text { the child's } \\
\text { communication in } \\
\text { the future }\end{array}$ \\
\hline
\end{tabular}


with the child

$\mid$ 
Table 3 Activities relevant to transition

\begin{tabular}{|l|l|l|}
\hline Transition Activity & Importance of activity & Value of Aid in Process \\
\hline Talking in front of class & Not important & Useful \\
\hline Visiting new places & Neutral & Useful \\
\hline Talking to new teacher & Neutral & Useful \\
\hline In meetings & Important & Useful \\
\hline Talking to new people & Important & Useful \\
\hline Making new friends & Important & Useful \\
\hline
\end{tabular}


Table 4 Activities relevant to new school

\begin{tabular}{|l|l|l|}
\hline Activity & Importance of activity & Value of Aid \\
\hline Drawing & Neutral & Useless \\
\hline Writing & Neutral & Neutral \\
\hline Planning & Neutral & Useful \\
\hline Punctuation & Important & Neutral \\
\hline Spelling & Important & Useful \\
\hline Handwriting & & Useful \\
\hline
\end{tabular}


Figure 1: Quality of life indicators chosen by children using aids which support recording and/or understanding

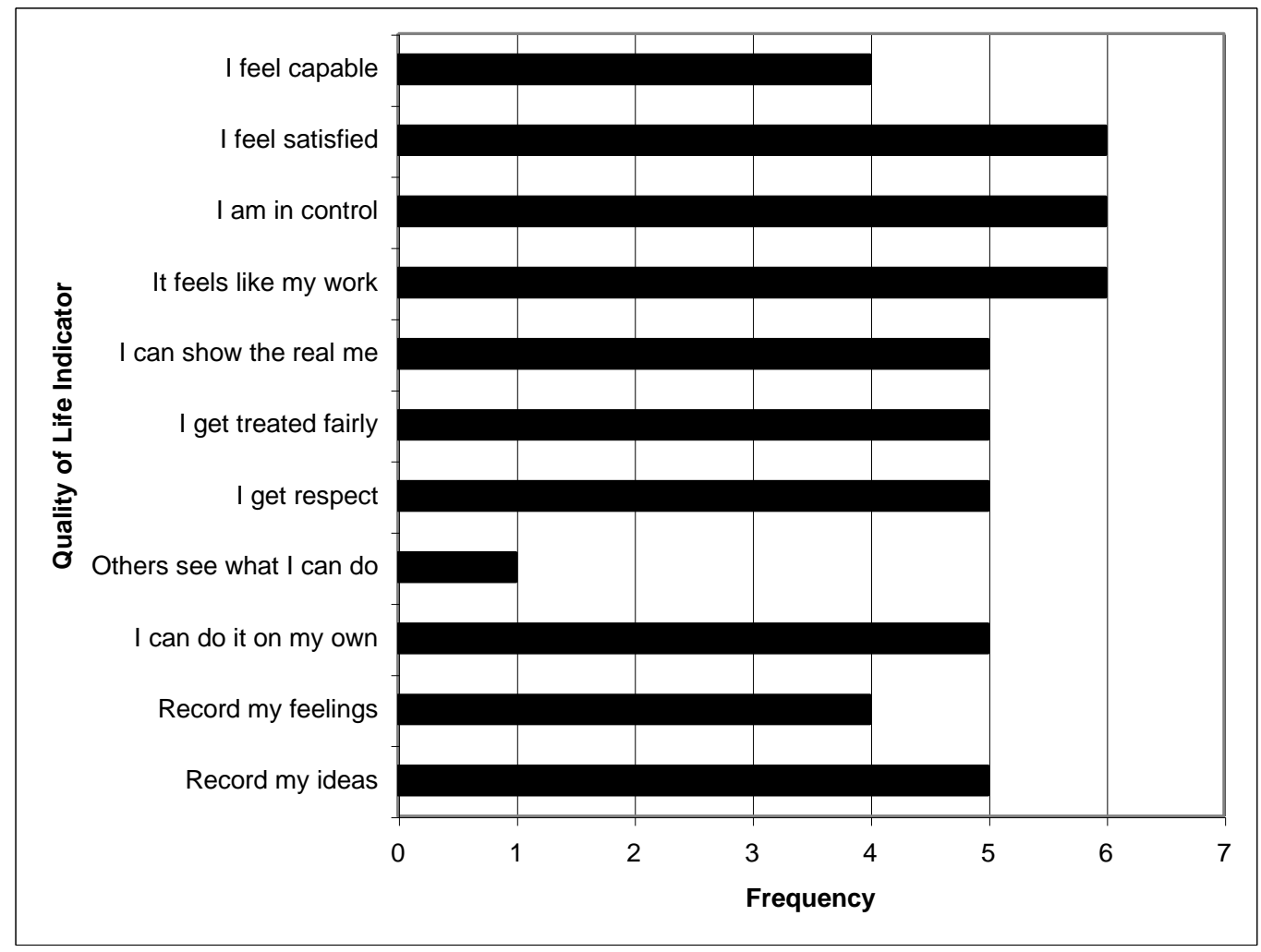


Figure 2: Quality of life indicators chosen by children using VOCAs

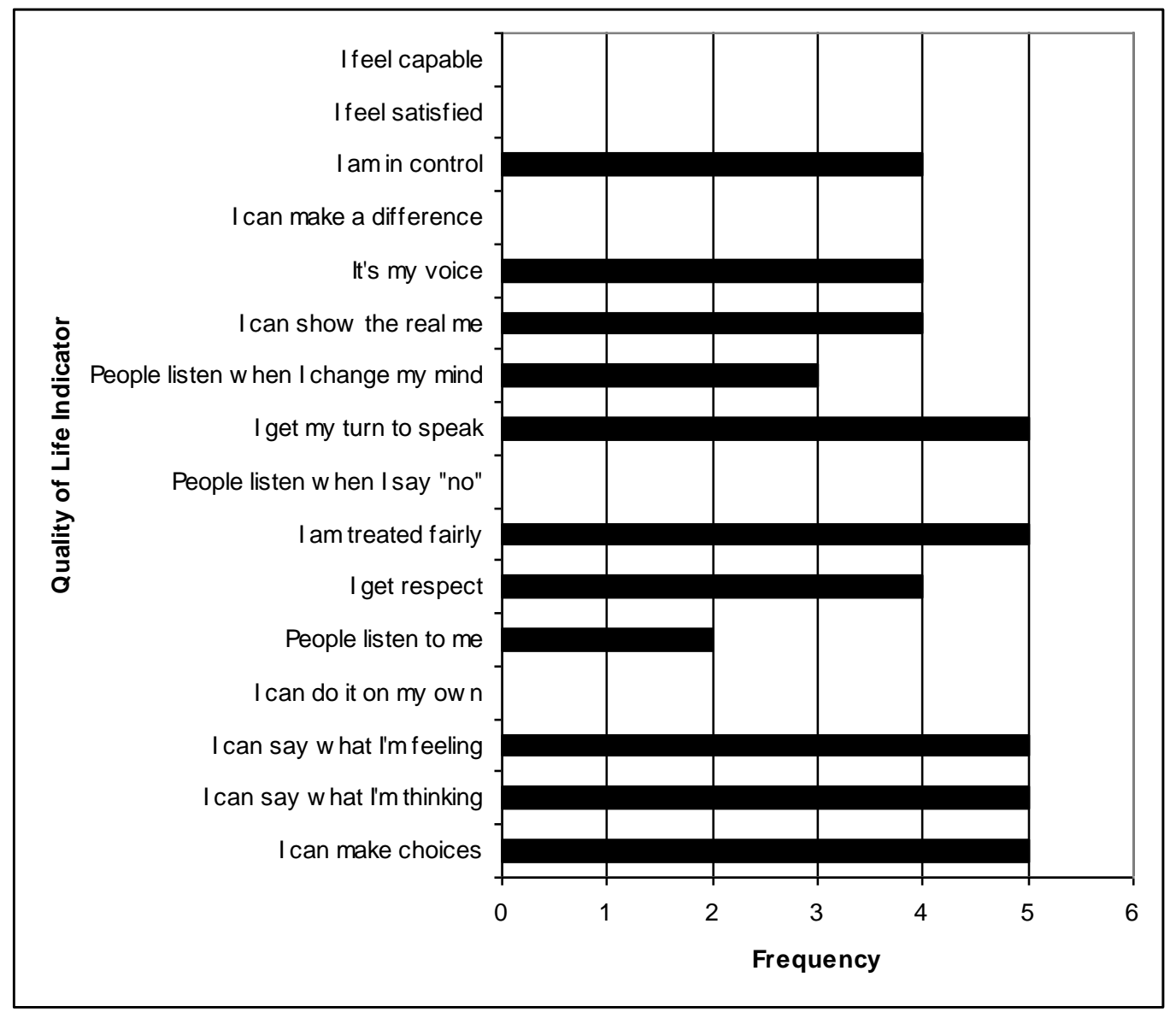

